\title{
ENTER DEEPLY
}

\author{
Niccolo Rocamora Vitug \\ University of Santo Tomas \\ niccolo.vitug@gmail.com
}

\begin{abstract}
About the Author
Niccolo Rocamora Vitug, an alumnus of the Silliman National Writers Workshop, graduated with an MA in Literary and Cultural Studies from the Ateneo de Manila University. He is presently taking his $\mathrm{PhD}$ in Music at the University of the Philippines, while teaching with the Department of Literature, Faculty of Arts and Letters, University of Santo Tomas. His collection Enter Deeply was selected as a finalist for the 2020 Gaudy Boy Poetry Book Prize.
\end{abstract}




\section{ENTER DEEPLY}

$$
\begin{aligned}
& \text { And so do with me as you please. } \\
& \text { - Lorenzo Ruiz }
\end{aligned}
$$

When you made your bed with your wife, Lorenzo, she bled by a force that ended in desire,

but blood, you would not see the end of it till it broke you and your companions, victims of a revolt not yours:

Your mission taken

apart by scholars, Christianity speared by Ieyasu's ban,

impaled by grandson Iemitsu,

lover and murderer of a young man

under pretext of betrayal:

$$
\text { It was all a sea of red: }
$$

Your wife and your absence, shogun and daimyo, lover and lover where red is the color of a violin's plaintive song. Will you have a song for your people, Lorenzo, if you lived today? 
I have just bitten

through summer's heart:

Zambales mango fully ripe, golden sap

dripping from my mouth.

I know where sweetness lies. I look to your statue unsure if something beats warmly there. 
I read the epistle

and follow your singing

of the psalm,

note per note gliding

down my ear.

This is what I wait for-

how the rostrum

marble warms slightly

to your touch,

how my palm

laps that all up

despite the silences

you throw in the lounge

for volunteers.

I give myself, volunteer

as sacrifice to you

if you will take me,

if each avoidance

is like the calling of Samuel-

veiled, insistent, strong

as the rise of my blood

inside my pants,

straining to be

your song rising

to heaven. 
Inscribe records

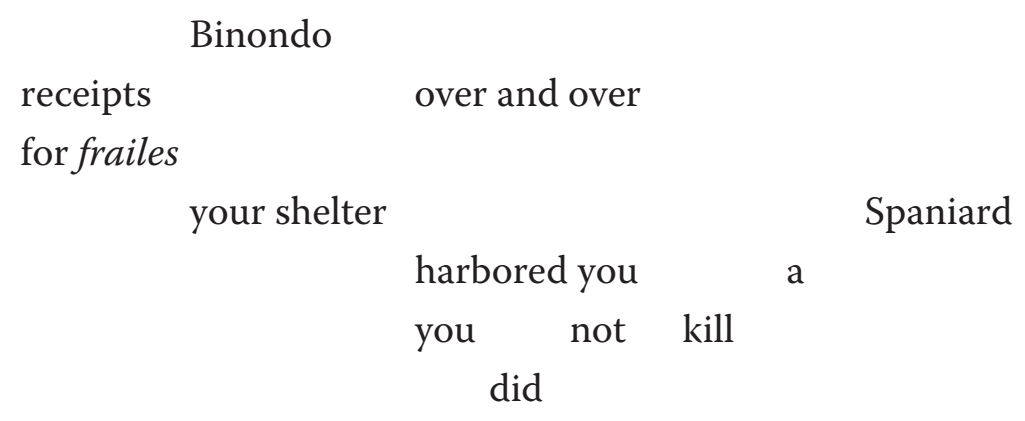

Inscribe crosses

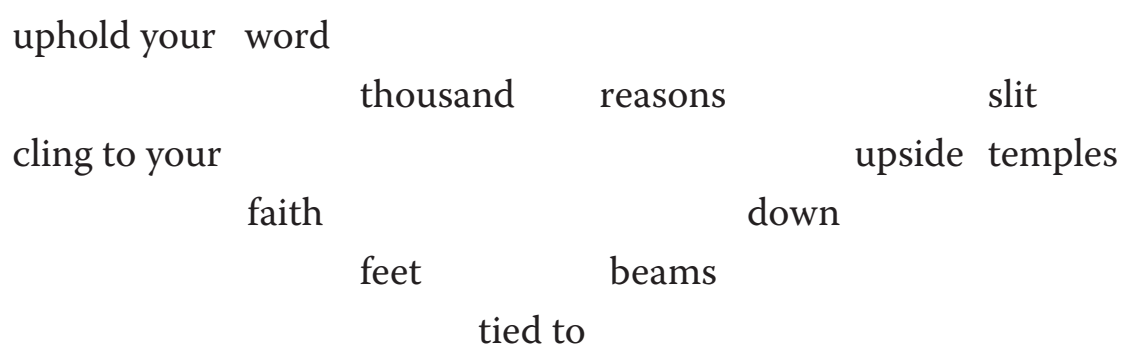

Amanuense

$\begin{array}{llr}\text { oneness of force } & & \text { ward } \\ \text { sky }\end{array}$


I told him not to go.

I told him I was scared.

He said he would be back.

He never came.

Los frailes already had use

of his elegant cursive.

His pittance of a payment

I had lent partly for profit.

I sold vegetables in the market.

I got into debt for more food.

I sung to our three children.

I always made payment.

I said he would return.

I wiped their tears.

I knew all along.

I survived without him.

I built our home.

The three found spouses.

The eldest took me in.

What else could I ask?

Did Lorenzo give himself to me

the way he pushed me off

when I clung on to him

as los frailes pulled him aboard?

I veiled myself in church.

You do not recognize me.

Lorenzo you know. Should he

be patron of anything? 
The martyr's palm frond

he holds in his hands?

I had a tree full of those

of the darkest green. 


$$
\begin{aligned}
& \text { I, Lazaro, the leper, } \\
& \text { have cherry blossom } \\
& \text { prints of dark pink } \\
& \text { from him who traded }
\end{aligned}
$$

sweetness with us, cargo of a vessel

and assault. He promised

larger than our sampans.

His thick fingers

$$
\begin{aligned}
& \text { are expert in sea } \\
& \text { parting. Together }
\end{aligned}
$$

to come back-a soreness

turned into rashes

that disappear,

$$
\begin{aligned}
& \text { we immersed } \\
& \text { in brine's pull }
\end{aligned}
$$
that return. A tree
overgrows

my insides. Take it

to the people

who shunned my faith.

My skin crumbles not!

Give me leave

to join Fray Gonzalez

\begin{abstract}
so that more dirty
blood colors
\end{abstract}

\section{my Kyoto and its storms, dark pink the shade}

to be scattered

on the seawater

in the breeze 
It is best this way: to make a show Of clot-stained water spouting As the board pounds my stomach Fever-high from all the tiredness While Lorenzo witnesses, torn linen Hanging at my side. He cannot see Gonzalez any less: lying in the same cell He calls Padre in pain, desperate For morning light to gentle the points On our fingers where knitting needles Were inserted. We are woven together: I took him in this mission, trusting him All these years, keeper of our records In cursive I can only hope to imitate. I cannot fray, if only for him, standing Stronger than the rest of us, likely One of the few offered martyrdom Among his people. I am not as gifted. May I have this bleeding before the pit A red stream as one last preaching.

If he be granted a protomartyr's glory, I would like to have a hand in it. 
This is how I died: I forgot I was dead, fully into the beads I had learned to pray over and over, coming apart in wounds and flayed skin. Light entered my flesh, soaking me chanting, "Full of grace, full of grace." I had no more rosary in my hand, but I smelled roses: those my mother brought home from church, those my wife bought at the market, the scent behind her ears as she strode me taking me fully, all grace. Suddenly I was taking her place, penetrated entered deeply, side hands head all my body's places. No more beads on the way to the pit, only fullness of grace, smell of dung and earth fading, and there was light breaking slowly on my face, my rising shivering from the groin shaking until there was only lightness clouds no more pit, no more beads, no more death. My face was wet, the sheets I lay on were wet: I stood up alive. 